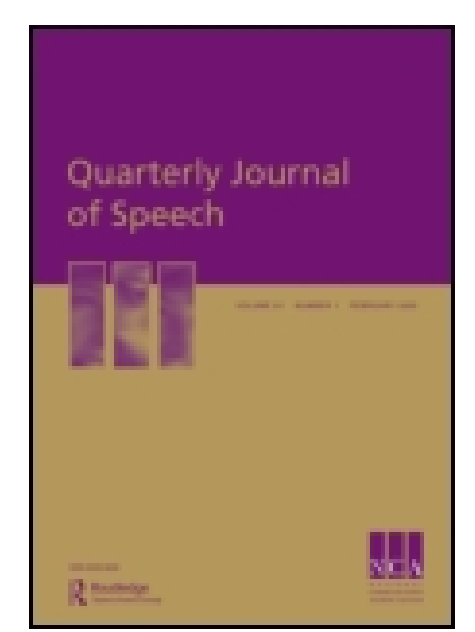

Quarterly J ournal of Speech

Publication details, including instructions for authors and subscription information:

http:// www.tandfonline.com/loi/ rajs20

\title{
An adventure in philosophy
}

Everett Lee Hunt ${ }^{a}$

a Huron College

Published online: 05 | un 2009.

To cite this article: Everett Lee Hunt (1917) An adventure in philosophy, Quarterly J ournal of Speech, 3:4, 297-303, DOI: 10.1080/00335631709360624

To link to this article: http:// dx. doi. org/ 10.1080/00335631709360624

\section{PLEASE SCROLL DOWN FOR ARTICLE}

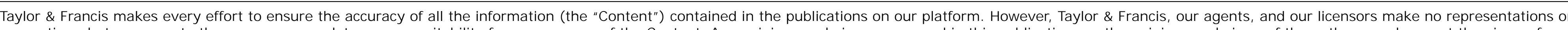

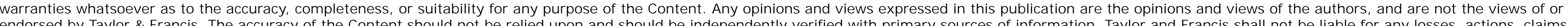

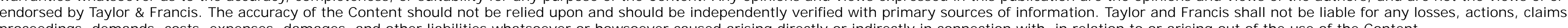
proceedings, demands, costs, expenses, damages, and other liabilities whatsoever or howsoever caused arising directly or indirectly in connection with, in relation to or arising out of the use of the Content.

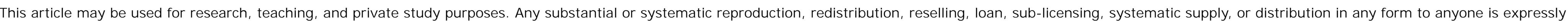
forbidden. Terms \& Conditions of access and use can be found at http://www.tandfonline.com/page/terms-and-conditions 


\title{
AN ADVENTURE IN PHILOSOPHY
}

\author{
EVERETT LEE HUNT \\ Huron College
}

$\mathrm{W}^{\mathrm{n}}$

E are making discoveries! We didn't know just what we were going to discover, or where it would be found. But we had made up our minds that something ought to be discovered; and a new theory, like wrong or evil, is sure to be found if you really look for it.

And our discoveries are coming in the fulness of time. Surely it were lamentable if, when dynasties are being dethroned, when morality is being subjected to a revaluation, when form is being banished from music, painting, and poetry, when education is in chaos, when philosophy is repudiating not only the timehonored solutions of questions that have been with us always, but even the questions themselves-surely it were too much to expect that we should refrain from revolutions. Our selfrespect demands them. Discoveries must come! And they come! Soon we shall have so many problems exclusively our own, and a terminology so adequate that, like the German professor quoted by Paulsen, "we can go so far that in a couple of sentences we can put ourselves where nobody can follow us." And then we shall be safe.

Randolph Bourne in an essay on Friendship says, "I do not spark automatically, but must have other minds to rub up against, and strike from them by friction the spark that will kindle my thoughts." And we all remember Macaulay's statement about the peg to hang his essay on. So I would not have this construed as an attack upon any discovery or discoverers. But I find myself reflecting upon the writings of the contributors to THE QUARTERLy Journal. They stimulate me. And sparks, if they come at all, come by friction. If to the serious minded my reflections seem flippant it is not because I do not regard the contributions as serious matters, but because I hold with Renan that "good humour is a philosophic state of mind; it seems to say to Nature that we take her no more seriously than she takes us. One should always speak of philosophy with a smile." 
When Quintilian attempted a theory and technique of oratory, not having had graduate work in psychology, he was compelled to base his system on Roman life and customs. Oratorical training was not so much a course of study as a way of living. And he doubtless labored under the impression that he was dealing with concepts that were fundamental. The medieval schoolmen, thinking logic to have several advantages over mere life, certainly thought they were deep down among the fundamentals when they propounded their logical formula. The exponents of the Delsarte method, with their triangles reminding one of Plato and the Pythagorean cults, were surely getting at the bottom of things. The legal mind that makes mutually exclusive definitions of conviction and persuasion is not aware that it is doing anything peculiar or abnormal. $\mathrm{He}$ is not "splitting hairs on the temples of truth"; he is making definitions that arise from the nature of things-assuming that things have a nature, which is dangerous. Wearied by all these artificial and superficial distinctions, Miss Yost proclaims that the real fundamentals are to be found in the field of sociology, and that distinctions not arising from the social situation are antiquated in oratory. And now Professor Woolbert, from his psychological laboratory, announces that "since mental processes can be described and explained (I have yet to learn of anything 'explained' by science) only in terms of psychology, the solution of the difficulty is to be found in psychology alone." So we move on to psychology in our search for fundamentals.

I myself am not quite so sure where the "fundamentals" will finally be discovered. In fact I am inclined to think "there ain't none." But that answer never satisfies, for someone is always asking "what is it that ain't?" And when we get to arguing over what the "fundamentals" are or where we can locate them, we have fallen among philosophers, and they spring up and choke us. Believing that fundamentals in anything lead us straight into philosophy, I venture to follow the elucidations from the sociologist and the psychologist with a plea for the philosopher. Were I an idealist with the fine scorn of science indulged in by the late Hugo Munsterberg I should meet the claims of the students in other fields with a vigorous pronouncement of the supremacy of philosophy. But believing as John Dewey has said in "The Recovery of Philosophy" that "Philosophy will have to sur- 
render all pretension to be peculiarly concerned with ultimate reality, with the real object," I make no such claim. On the contrary the suggestion that I should take from philosophy would be that any claim of any one branch of learning to be final or "fundamental" should be very carefully examined. Instead of offering a contribution from philosophy, then, I merely attempt warning.

I do not quarrel with Miss Yost or Professor Woolbert in their desire to do away with misleading distinctions. I hope they will bury many of them. But there is a habit of mind, as old as philosophy itself, which, when it sees the unreality of many supposed differences and distinctions, attempts to force everything into an all-embracing unity. It is this type of thinking that I find in Professor Woolbert's statement of the problem of belief and action: "In what terms can you state the unity so that there will be no omissions?" What I fear is that this cannot be done. Professor Woolbert's statement is much like the now largely abandoned attempt of philosophers to find some one generality of which everything in the universe is an example. Of course, if you are bent on synthesizing, you can put belief and action-or most anything else-together. You can go as far as Hegel and declare that you cannot get the whole truth until you have reconciled all contradictions in the Absolute. Or if you are fond of analysis and are as clever as the neo-realists at it, you can analyze anything until there is nothing left. You can even analyze motion into its component parts without affecting the movement. But all this might involve some delay in making clear to freshmen one's position on the conviction and persuasion controversy. Professor Woolbert says the issue is: "Are belief and action two different entities, or are they one and the same thing?" I confess that I am as unable to locate the issue in any one place as Professor Woolbert is to find a real dividing line between belief and action. If I were disposed to be argumentative I might accept his monism and then say that the dualism is not between belief and action, but between theory, or a theoretical attitude of mind, and Professor Woolbert's "response." Leslie Stephen, in "An Agnostic's Apology" says, "The man has most faith, in the sense in which faith represents a real force, whose convictions are most favorable to energetic action, and is freest from the doubts which paralyze the will in the great moments of 
life." Now if we take from this a definition of belief as "a conviction favorable to action," then Professor Woolbert's destruction of the distinction between belief and action is easy. You can go further with him and say that thinking is acting, though it may not be the "response" you as a speaker desire. But what shall we say of that thinking which is not believing, but is theorizing? Even the man in the street knows that theorizing is inimical to action. But if theorizing is thinking, and theorizing destroys action, then we have again fallen into a dualism between thought and action. If this dualism exists in the audience, the speaker must overcome this before he can get his coveted "response." But to harmonize the conflicting elements of doubt into "conviction favorable to action" is essentially a logical process; and the motivation of the belief after it is secured is surely a different process. Thus I have accepted Professor Woolbert's monism, but by shifting the issue to theory and belief I have discovered another dualism. Your monist might embarrass me by asking me to locate the boundaries between theory and belief, and thus cast a doubt on the validity of the distinction. But my point is, if you are after distinctions you can make them almost anywhere. Or if you are bent upon destroying them, you can analyze them away at any time.

Thus by indulging two opposite habits of mind, the debate might be kept up ad nauseam or ad infinitum, according to one's enthusiasm and endurance. With equal facility the psychologist finds reasons for synthesizing when he wants to destroy old distinctions, and reasons for analyzing when he wants to make new ones of his own. The issue is not so much between the new and old distinctions as it is between the mental processes. And by psychological arguments I suppose either process might be proved right or wrong. For myself, I prefer to drop the notion that there is anything in the situation which compels me to do either. I have to confess with an eighteenth century writer that I use my logic to find reasons for what I want to do. Therefore I decline to take seriously the bonds either of the traditional terms or of revolutionary discoveries. They can be equally tyrannical. Anatole France in his "Revolt of the Angels" presents a well-worn truth cleverly when he pictures Satan, after overcoming God, as taking on all the characteristics of God. Using a term of William James's I would accuse all who place emphasis on 
terminology - a terminology hoary with age, or a terminology in the latest and most approved "terms of stimulus-response, objectsubject, or environment attitude"-of "vicious intellectualism."

This demand for a restatement of rhetoric in terms of psychology reminds one of Aristotle's observations on the similarity of grammar and philosophy. And yet even though a child, every time he diagrams a sentence, makes enough philosophical assumptions to keep wise men debating eternally, we do not try to state his grammar for him in terms of philosophy. This attempt to find "terms in which you can state the unity so there will be no omissions" is so typical of the monistic habit of mind that I cannot refrain from quoting William James again, this time from the Pluralistic Universe.

"All philosophers have conceived of the whole world after the analogy of some particular feature of it which has particularly captivated their attention. Thus the theists take their cue from manufacture, the pantheists from growth. . . . . Some thinkers follow suggestions from human life, and treat the universe as if it were essentially a place in which ideals are realized. Others are struck more by its lower feature and for them brute necessities express its character better. All follow one analogy or another; and all the analogies are with some one or other of the universe's subdivisions. Everyone is nevertheless prone to claim that his conclusions are the only logical ones and that they are necessities of universal reason, they being all the while, at bottom, accidents more or less of personal vision which had far better be avowed as such."

Not only does the attempt to compel teachers of Public Speaking to borrow their terms from psychology seem to be an example of this "personal vision," but the attempt to determine which particular psychological terms shall be used seems to exaggerate the importance of terminology and to make again the mistake of assuming that certain ideas are inherently "fundamental." In a footnote on page 254 of the July Quarterly Journal Professor Woolbert says that action as "response" seems to him a more "fundamental" word than Professor Winans' key word of Attention. Now I will admit that from Professor Woolbert's point of view it may be a more general concept, but to honor it with the term more "fundamental" is to give it a fictitious value. Whether or not it is more "fundamental" depends on who is using it 
and for what purpose. Thus to refer to William James again, to me the "fundamental" thing about the paper on which I am writing is that it will receive my ideas (if no one else will), while to another man its chemical properties might be "fundamental."

When you attempt to isolate and mark out certain concepts. as in themselves "fundamental," you are dealing with abstractions. As John Dewey has somewhere said, whenever you abstract a principle from a situation, there will come a time when that situation and that principle are in conflict. The futility of the attempt to insist on "fundamental concepts" is further shown by the quickness with which any term acquires a strictly limited technical meaning unintelligible to one not familiar with the subject matter. Thus to say that the late Josiah Royce was an idealist and that President Wilson is an idealist is to make statements widely different in their significance. And it would add nothing to the knowledge of the much abused man in the street to say that the notion of idealism was fundamental in interpreting the two men.

Whatever thinking is done clearly and definitely, if it bears labels and technical terms, will be borrowed and used blunderingly by lesser men. Which, of course, is but to repeat "the letter killeth!" Where is there so much misunderstanding as among the philosophers who spend their time making definitions? This is not to minimize the importance of exact thinking, but it is to emphasize the vanity of the hope in words, it is to emphasize the necessity of eschewing abstractions and of keeping to the concrete and particular. As many possibilities for abuse lie in the word "response" as in "conviction." Who has not suffered from "efficiency," "service," "uplift," "community welfare," in the mouths of bores?

Any closed system is sure to meet this fate. It is easy to see the inadequacies of old systems and terminologies because we have transcended them in our own experience. And when we get a system that pretty completely expresses our own experience we imagine it complete.

Again I repeat that these remarks are not attacks upon Miss Yost or Professor Woolbert. Their service is of incalculable value. But now that teachers of public speaking are awaking to the joy of scholarship or to the stern fact that they must become scholars, the science of speech, if such there be, will be formed 
largely by analogies from other fields. In this process of building up a new content, I have only these suggestions to offer:

(1) No one science can rightfully claim to be fundamental in shaping the concepts of public speaking.

(2) No one formula can be discovered which will express the whole process.

(3) Distinctions and definitions are by their very nature little more than half truths, and their inadequacies can never be remedied by a new terminology. 